Table 2. INHIBITION of Phosphorus-32-Phosphate UPTake INTO Phosphate Fractions of The Celi BY 8-Azagdanine AND BY $p$-FLUOROPHENYLALANINE

\begin{tabular}{|c|c|c|c|}
\hline \multirow{2}{*}{ Inhibitor } & $\begin{array}{c}\text { Acid-soluble } \\
\text { organic } \\
\text { phosphate }\end{array}$ & $\begin{array}{c}\text { Ribonucleic } \\
\text { acid phosphate }\end{array}$ & $\begin{array}{c}\text { Deoxyribonucleic } \\
\text { acid phosphate }\end{array}$ \\
\cline { 2 - 4 } & 70 & 72 & 53 \\
\hline $\begin{array}{c}\text { 8-Azaguanine } \\
\text { 300 } \text { agm./ml. } \\
p \text {-Fluoro- } \\
\text { phenylalan- } \\
\text { ine 300 } \\
\mu \mathrm{gm} . / \mathrm{ml} .\end{array}$ & 100 & 98 & 81 \\
\hline
\end{tabular}

Cell suspensions were incubated for $1 \mathrm{hr}$. with phosphorus-32-phos phate after a 4-hr. period of pre-incubation with inhibitor.

tent with this interpretation is the finding (Table 2) that in a concentration $(300 \mu \mathrm{gm}$. per ml.) at which 8-azaguanine has a 35 per cent inhibitory effect on antibody synthesis (cf. Fig. 1) there is a similar (30 per cent) reduction in phosphate turnover in the acid-soluble phosphate pool. Thus, though 8-azaguanine inhibits antibody formation, this is not an isolated event, but rather a manifestation of a general suppression of spleen cell function.

This tentative interpretation of the spleen cell system, however, is subject to several limitations. Amino-acid incorporation into antibody, made only in a small proportion of the cells, has been compared with amino-acid incorporation into a poorly characterized protein isolated from the whole cell population. Moreover, a considerable fraction of the latter appear to be dying ${ }^{3}$. Finally, in induced enzyme formation, it is the inhibition of the ability to begin making new protein which is measured, whereas, in the present system, it is the inhibition of the ability to continue to make new protein which has been measured.

Further experiments designed to approach these points are in progress. This work was supported by U.S. Public Health Services grant E1305.

R. W. DUtToN*

ANNe H. DutTon*

MARIAM GEORGE*

Medical College of Virginia,

Richmond 19, Virginia.

- Present address: University of Rochester Medical Center, Rochester 20, New York.

${ }^{1}$ Creaser, X. H., Biochem. J., 64, 539 (1956).

2 Burnet, "Enzyme Antigen and Virus, a Study of Mracomolecular Pattern in Action" (Univ. Press, Cambridge, 1956).

${ }^{3}$ Vaughan, J. H., Dutton, A. H., Dutton, R. W., George, M., and Marston, R. Q. (in preparation).

\section{Distribution of Choline Acetylase in Insect Conductive Tissue}

IT has been clearly shown that insects contain acetylcholine, cholinesterase and choline acetylase, and the work of Smallman ${ }^{1-3}$ has done much to evaluate these. Since then, a more specific study of the substrate and enzymes in the conductive tissue of the American cockroach, Periplaneta americana L., has shown that acetylcholine occurs most abundantly in the brain and ganglionic tissue of the central nervous system ${ }^{4}$, that the amount of acetylcholine increases after treatment with anticholinesterases when the nervous system shows intense electrical activity ${ }^{5}$, and that acetylcholine is found in blood at this time $e^{6}$. These facts are compatible with those found for vertebrates.

A further step in the evaluation of the role of acetylcholine has now been taken by determining the distri-

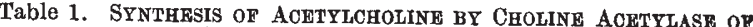
Cockroach Conductive Tissue

\begin{tabular}{|l|c|}
\hline \multicolumn{1}{|c|}{ Tissue } & $\begin{array}{c}\text { Rate of acetylcholine } \\
\text { synthesis } \\
\text { (mgm./gm./hr.) }\end{array}$ \\
\hline Brain & $50 \cdot 6$ \\
Brain + sub-cesophageal ganglion & $53 \cdot 0$ \\
Ganglia of thoracic nerve cord & $20 \cdot 8$ \\
Sixth abdominal ganglion & $18 \cdot 0$ \\
Thoracic nerve cord & $11 \cdot 4$ \\
Ventral nerve cord & $10 \cdot 6$ \\
Abdominal nerve cord & $6 \cdot 2$ \\
Connectives of the thoracic nerve cord & $2 \cdot 6$ \\
Fifth leg nerve & $2 \cdot 0$ \\
Coxal muscle & 0 \\
Flight muscle & 0 \\
\hline
\end{tabular}

bution of choline acetylase in conductive tissue of the cockroach. This work was carried out with homogenates of tissues, as more purified enzyme prepara. tions required impractical amounts of tissue. The activity of choline acetylase of homogenates was determined by the amount of acetylcholine formed in incubates containing coenzyme $A$, acetyl phosphate, transacetylase, choline, salts and buffer (Mehrotra, K. N., and Chefurka, W., private communication). The rate of acetylcholine formation was linear for the incubation period of $15 \mathrm{~min}$., and all work was carried out at $30^{\circ} \mathrm{C}$., the experimentally determined temperature optimum for choline acetylase from both cockroach and housefly. This optimum is close to that found for insect eggs (Mehrotra, K. N., and Chefurka, W., private communication). Table 1 shows the rates of acetylcholine synthesis for nervous and muscle tissue. It is at once evident that the brain and thoracic ganglia contain the highest amount of choline acetylase. The results for the distribution of choline acetylase are striking, for they compare favourably with the distribution of acetylcholine ${ }^{4}$ in the same tissues. Furthermore, the intracellular distribution of choline acetylase appears to be similar to that found for acetylcholine. At tissue weights equivalent to and in excess of that for nervous tissue, no synthesis was found in cockroach leg muscle. This observation is of interest for, as yet, no detectable amount of acetylcholine has been found in denervated cockroach muscle? ${ }^{7}$ The synthesis-rate for cockroach brain is the highest yet reported for acetylcholine synthesis in either vertebrates or invertebrate conductive tissue.

The importance of the functional role of acetylcholine in insects must be considered in view of this evidence for the occurrence and distribution of acetylcholine and related enzymes in the nervous system of the cockroach, and the lack of evidence for physiologically significant amounts of other neurohormones. The details of this work and observations on the tissue distribution of cholinesterase will be published more fully elsewhere.

\section{E. H. CoLhoun}

Science Service Laboratory,

Canada Department of Agriculture,

University Sub Post Office, London, Ontario.

Aug. 27.

Chefurka W. and Smallman, B. N., Canad. J. Biochem. Physiol. 34, 731 (1956)

${ }^{2}$ Smallman, B. N., and Wolfe, L. S., J. Cell. Comp. Physiol., 48, 197 $(1956)$.

s Smallman, B. N., J. Physiol., 132, 343 (1956).

4 Colhoun, E. H., J. Insect Physiol., 2, 108 (1958).

${ }^{5}$ Colhoun, E. H., J. Insect Physiol., 2, 117 (1958).

- Colhoun, E. H., Science, 127, 25 (1958).

$\checkmark$ Colhoun, E. H. (unpublished work) 